\title{
深く埋込まれた構造物の地震時側面土圧の挙動に関する実験的研究 EXPERIMENTAL AND ANALYTICAL STUDIES OF LATERAL SEISMIC EARTH PRESSURE ON A DEEPLY EMBEDDED BUILDING MODEL
}

\author{
内山正次*, 山下利夫** \\ Shoji UCHIYAMA and Toshio YAMASHITA
}

Analytical studies concerning lateral seismic earth pressure on a building model are summarized as follows.

1. Lateral earth pressure on a deeply embedded building model during an earthquake is composed of relatively long-period lateral earth pressure with the same phases on opposite sides and short-period lateral earth pressure with reversed phases on opposite sides, of which period is shorter than the fundamental natural frequncy of the building.

2. The observed characteristics of lateral earth pressures, concerning amplitude and phase, can be well reproduced by multiinput analysis based on the observed waves under the ground.

3. Amplitude and phase of lateral earth pressure are remarkably influenced by the incident angles of input motions. The observed amplitude and phase of lateral earth pressure are well reproduced by analyses with the assumption of 5 to 10 degrees as the incident angle of input motion. These angles are coincident with the general incident angles of actual earthquakes.

Keywords: Building model, Lateral seismic earth pressure, Multi-input analysis, Inclined input analysis, Incident angles 構造物模型, 地震時側面土圧, 多入力解析, 斜め入射解析, 入射角

1.はじめに

原子力発電所等に代表される埋込みのある大型構造物の設計に関 しては、高度な地震応答解析法が種々用いられているが、その耐震 設計の重要性に鑑み、その実証性を深めるために多くの研究がなさ れている1)ー3)。これらの一環として埋込みの梁い実構造物やそれを 模擬した構造物模型に土圧計を設置し、地震時の土圧観測が行なわ れているが、観湘された相対する地下部側面の土圧は、通常の地震 応答解析で用いられるSH波鉛直入射の条件では表し得ない同位相を 示す場合があることが指摘されている4) 5)。そのため、以下におい て構造物模型を対象とした地震時の土圧の観測記録の分析と解析的 検討結果について述べる。

\section{2. 構造物模型と敷地地盤の概要}

図 1 に構造物模型試験体を示す。その棈造は、地下 1 階、地上 2 階の鉄筋コンクリート造構造物である。構造物模型の寸法は全体の

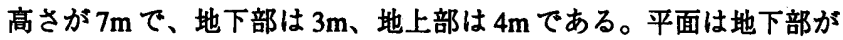
$6 \mathrm{~m} \times 6 \mathrm{~m}$ 、地上部が $3.1 \mathrm{~m} \times 3.1 \mathrm{~m}$ の正方形の構造物である。構造的 には、地階と 1 階が壁式構造、2 階は 4 隅で L 字型柱でR 階スラプ を支持している比較的柔な構造となっている。この構造物模型を構 築するにあたり図2に示すごとく地盤を掘削した。根切り深さはGL-

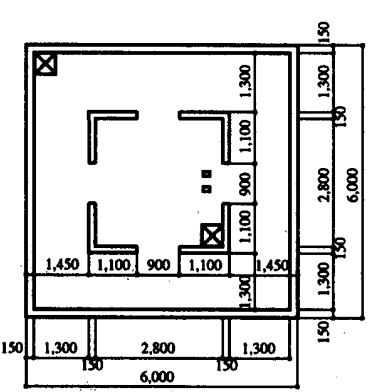

地陵平面図

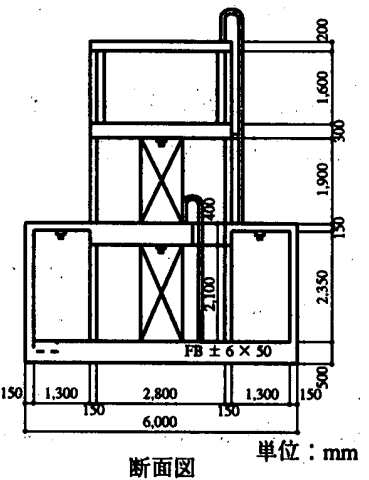

図 1 構造物模型試験体

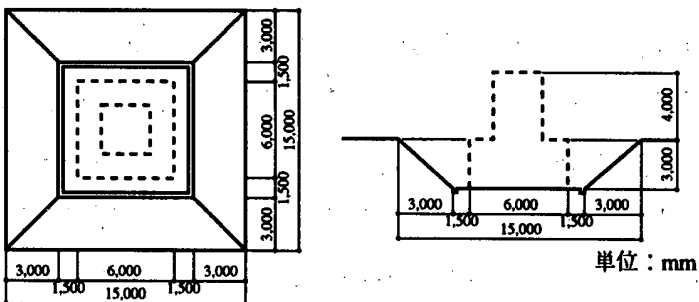

図 2 周辺地盤掘削状況
本論文は，参考文献11で既に発表したものを加籍したものである。

* 鹿島技術研究所 専門部長・工修

** 東京電力踭原子力技術部 建築グループマネージャー 副部長・工博
Senior Manager, Kajima Technical Research Institute, Kajima Corp., M. Eng. Deputy General Manager \& Group Manager, Architectural Engineering Nuclear Power Engineering Dept., Tokyo Electric Power Company, Dr. Eng. 


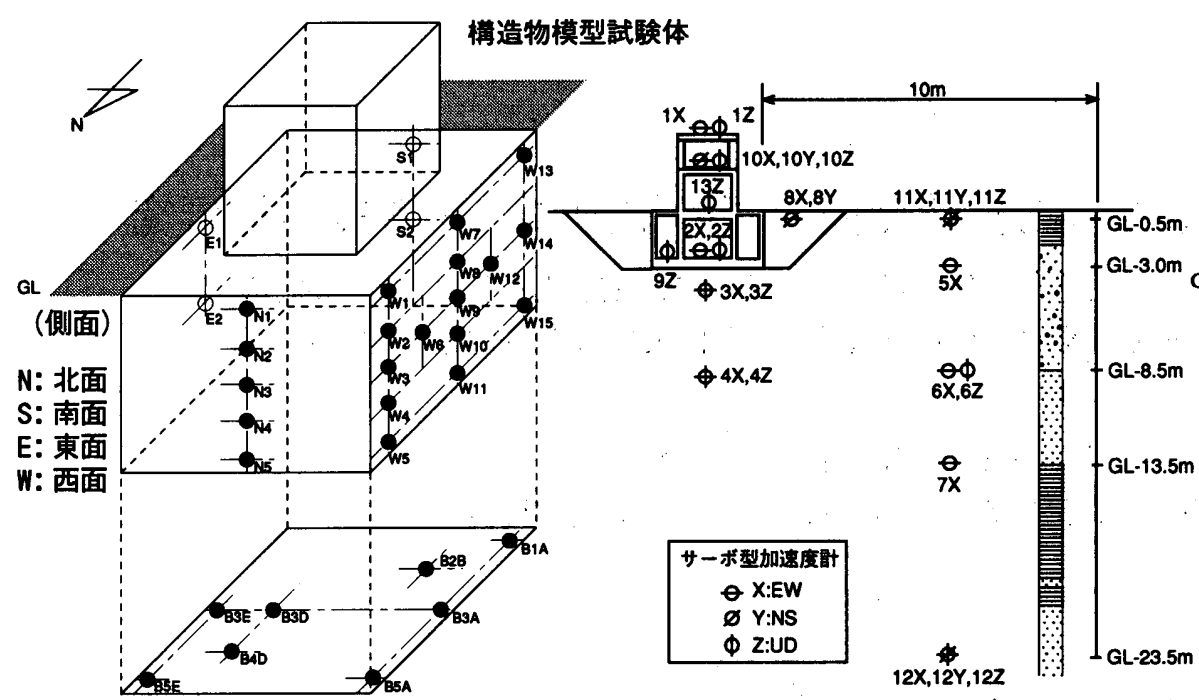

(底面)

図3 土圧計設置位置

図 4 地震観湘点設置図

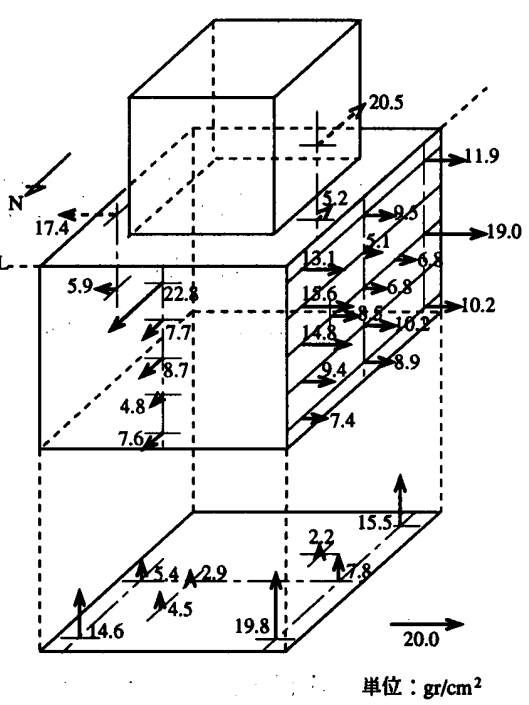

図 5 地震時土圧記録の最大值分布 （福島県沖 : 1985.8.12）
$3 \mathrm{~m}$ で根切り底の平面は $9 \mathrm{~m} \times 9 \mathrm{~m}$ である。法面の傾斜は 45 度として おり、地表部法局平面は $15 \mathrm{~m} \times 15 \mathrm{~m}$ となっている。なお構造物模型 の総重量は約106tonでこれは構造物地下部の排土重量のほほ60\%に あたる。また、構造物模型が設固されている敷地は大別して GL$23.5 \mathrm{~m}$ までは上位から Vs=270 430 $\mathrm{m} / \mathrm{sec}$ の第四紀層、GL-23.5m 以 深は Vs=500 700m/sec の第三紀層から構成されている。構造物模 型周辺は川砂を用いて、均質な密度になるように転圧して埋戻され ている。当該構造物模型は深く埋め込まれた構造物の動的相互作用 特性に関する埋戻し前後の振動実験と地震観測が実施され、実験 ・ 解析的検討が報告されている ${ }^{6}$ 。

\section{3. 地震時土圧観測記録の分析} 3.1 土圧記録最大值分布
W7-E1
構造物模型に設置された土圧計の配置を図 3 に示す。また、構造 物及び周辺地盤の地震観測点配置を図 4 に示す。1985年 8 月 12 日福 島県沖地震 $(M=6.4, \Delta=82 \mathrm{~km}, \mathrm{D}=52 \mathrm{~km})$ で観測された側面と底面の地震 時の土圧記録の最大值分布を図 5 に示す。地表で $50 \sim 60 \mathrm{Gal}$ の最大 加速度に対して側面で $20 \mathrm{gr} / \mathrm{cm}^{2}$ 、底面でも $20 \mathrm{gr} / \mathrm{cm}^{2}$ 程度の土圧に なっている。その分布についてみると、壁面の中央が小さく端部が 大きくなる傾向を示している。この現象については、M.Narikawaら 7!による土圧の 3 次元効果に関する検討によると、これらの土圧の値 とその分布形状の傾向とも SH 波鉛直一様入射による 3 次元 FEM 解 析により、かなりよい対応が得られることが報告されている。

\section{2 土压記録の時刻歷特性}

前記の地震で得られた土圧記録に関し、相対する側面土圧の時刻 歴波形の主要動部分と後半部分の各 2 ヶ所を拡大し、重ね書きして

\section{N1-S1}
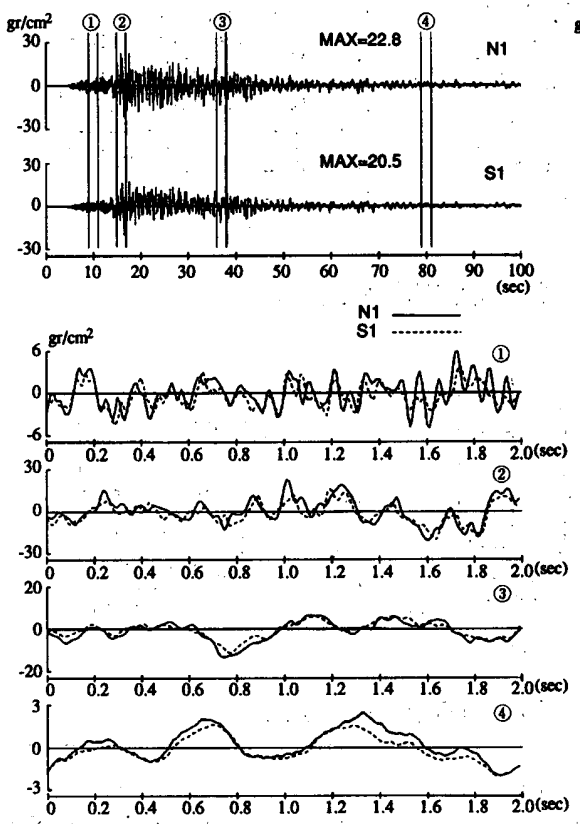

図 6 側面土圧記録の重ね書き（NS 方向）

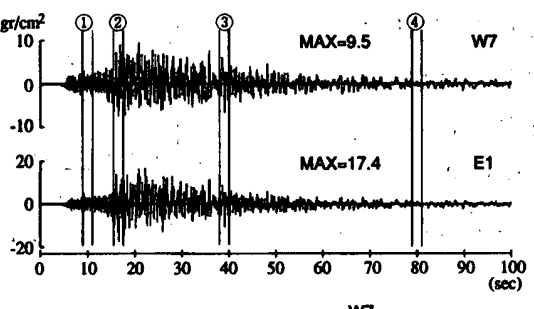

E1

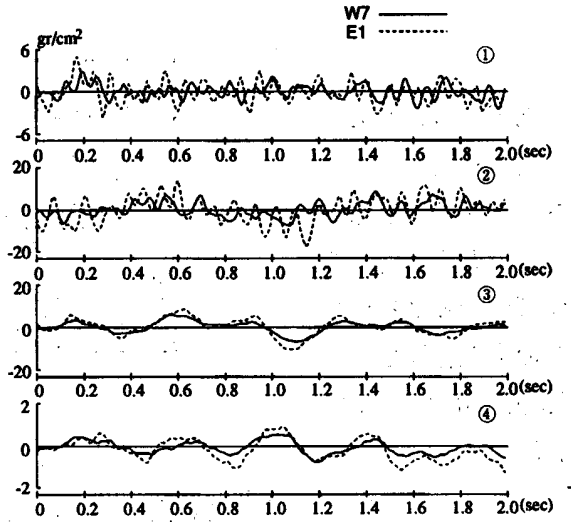

W7-B3A
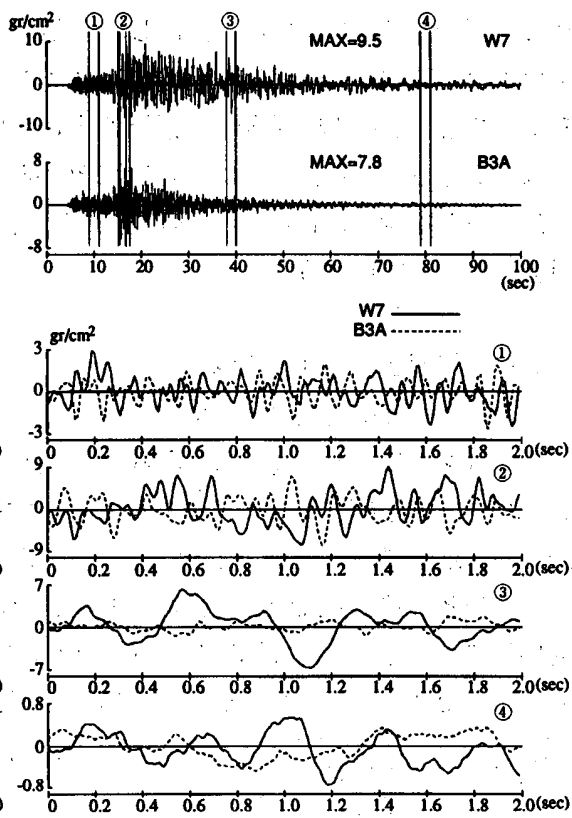

図 8 側面と底面土圧記録の重ね書き（EW と上下） 
図 6〜図 7 に示す。また同様に、側面土圧と底面土圧を重ね書きし たものを図8に示す。これらの結果は以下のようにまとめられる。

図 6 と図7に示すNS方向(N1-S1)と EW 方向(W7-E1)の相対する側 面土圧は、かならずしも逆位相（圧縮一引張）ではなく、此較的低 振動数の同位相 (圧繟一庄縮、引張一引張)の土圧が顕著に現れ、そ の傾向は主要動以後に特に強い。地震の後半では実体波はほほ減衰 しており表面波が卓越しているものと考えられ、構造物の加速度応 答は小さいが比較的大きな側面土圧が同位相で生じている。また、 波形を拡大した前半の(1)，(2)を詳細に見ると、全体的に同位相と なっている低振動数成分の波に、部分的に逆位相の傾向が強い高振 動数成分が含まれている。これは構造物〜地盤連成系の動的相互作 用において構造物模型の慣性力が大きく、周辺地盤の震動より相対 的に構造物模型が大きく震動するためと考えられる。

構造物模型の 1 次共振振動数 $12.3 \mathrm{~Hz}$ 付近ではロッキング成分が卓 越する。この場合、図 8に示す㑡面土圧(W7)と底面土圧(B3A)の関係 は図 3に示す土圧計設置位置から同位相となる。应大波形(1)をみる と土圧值の大きくなる高振動数成分で同位相の傾向が見られるがあ まり明瞭ではない。主要動部分の(2)をみても側面土圧と底面土圧の 相関関係は認められない。特に地震の後半になると、相対する側面 位置に見られるような相関関係は見られす、ロッキング成分を含む 上下動が地下部側面の土圧に及ほす影響は小さいと考えられる。

\section{3 土圧記録の振動数特性}

1984 年 12 月 19 日福島県沖地震 $(M=5.3, \Delta=72 \mathrm{~km}, \mathrm{D}=44 \mathrm{~km})$ を対象 に土圧の振動数特性を調べた。構造物模型の側面土圧のフーリェス ペクトルを図 9 に示す。また、構造物模型の 1 次共振振動数付近を 含めて低振動数領域と高振動数領域の 4 組の振動数帯域を選びバン ドパスフィルターを通した。図 10 にバンド幅 $2.0 \sim 3.0 \mathrm{~Hz}$ とした時 の相対する側面土圧の時刻歷波形例を比較して示した。最大值、振 幅包絡形ともほほ同じであり、明瞭な同位相となっていることが分 かる。相対する側面土圧の位相関係をより明確にするため、バンド パスフィルター処理後の土圧のオービットを図 11 に示した。構造物 模型の 1 次共振振動数より低振動数域のバンド幅 $2.0 \sim 3.0 \mathrm{~Hz}$ では、 いずれも同位相となっているが、バンド幅 $18.0 〜 19.0 \mathrm{~Hz} て ゙ は \mathrm{NS}$ 方 向、EW方向とも逆位相となっている。また、構造物模型の 1 次共振 振動数近傍のバンド幅 $10.5 \sim 11.5 \mathrm{~Hz} 、 13.5 \sim 14.5 \mathrm{~Hz}$ では、NS、EW の方向により差はあるが、ほほその中間的傾向を示す。振動数に応 じて一様の傾向を示すとは限らず、同位相、逆位相が振動数に応じ て交互に現れたり、構造物模型の 1 次共振振動数近傍でも同位相の 土圧が現れるなど明確な傾向を持たず、過渡的な現象が現れている ものと考えられる。

\section{4 考察}

構造物模型の地下部外壁に作用する土圧は、相対する側面位置に おいてかならずしも逆位相ではなく、構造物模型の 1 次共振振動数 よりも低振動数領域で顕著にみられる同位相土圧と、構造物模型の 1 次共振振動数近傍またはそれ以上の振動数領域で発生する逆位相 土圧の合成波形となっていることが分かる。これより地震動の構造 物模型への入力がかならずしも鉛直入射のSH波的な伝播ではなく、 SH 波やSV 波の斜め入射、また入射地震波が空間的に変動する影響 が土圧観測結果に現れているものと考えられる。

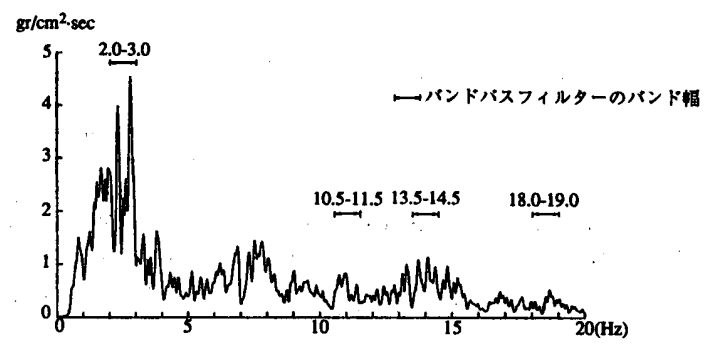

図 9 側面土圧 (W7) のフーリエスペクトル

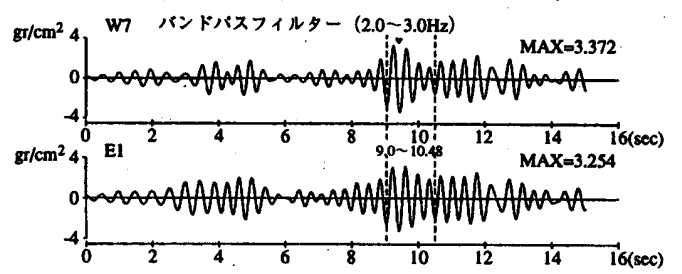

図 10 バンドパスフィルター処理後の時刻歴波形

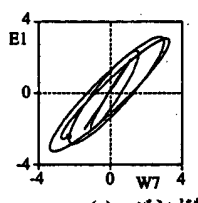

(a) バンド帽: $2.0 \sim 3.0 \mathrm{~Hz}$

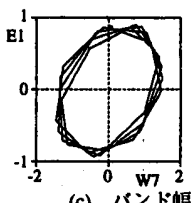

(c) パンド帽: 13.5 14.5Hz

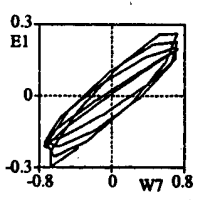

(b) バンド幅：10.5 11.5Hz

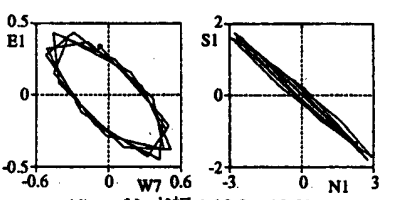

(d) バンド幅 : $18.0 \sim 19.0 \mathrm{~Hz}$
図 11 側面対称位置のオービット

\section{4. 锶測記録に基つく多入力地霆動による評価}

構造物〜地盤連成系解析モデルによる地震応答解析を行なう場合、 一般には工学的基盤または解析モデルの底面に一様な入力地霞動を 想定している。しかしながら種々のアレー地震観測記録など8)により 明らかにされているように地震動の振幅、位相特性は平面的な位置 の違いにより互いに差がみられる。このように振幅・位相に差を有 する地震波を考えた場合、一様な入力では説明し得ない構造物模型 の地下部側面における相対する地震時の土圧の同位相特性を説明で きる可能性を考えて、2 観測点で観測された観測記録から地霞動を 推定し、これらを入力とした多入力解析を行なった。

\section{1 解析方法}

通常の地震応答解析では地震動が鉛直方向から平面的に一㥞入力 すると仮定して行うが、ここでは振幅及び位相も一様ではなく、入 力地点により異なる地震動が入力されると考える。解析対象とした 構造物模型の地霞観湘では構造物の直下の観湘点 (4X) とその観測 点より $13.0 \mathrm{~m}$ 離れた自由地盤系の観測点（6X）の 2 ケ所に GL-8.5m の深さで水平方向の加速度計が設置されている。そこで GL-8.5m 以 浅の構造物〜地盤連成系モデルを作成し、2 観測点で観測された記 録波から同じ深さの任意の地点の地震動を推定し、これらを入力と した多入力解析を行う。 


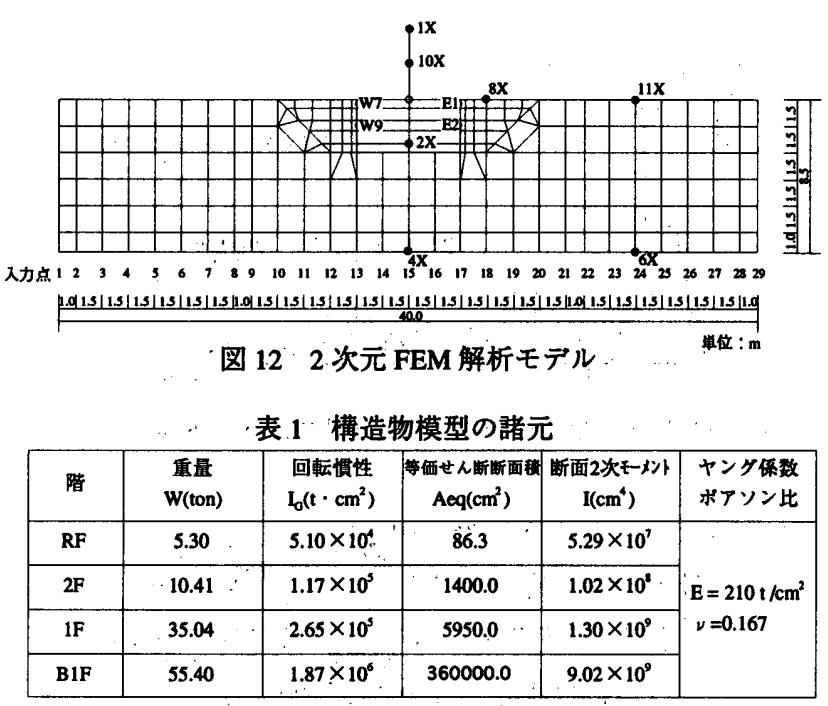

表 2、地盤物性一覧

\begin{tabular}{|c|c|c|c|c|c|c|}
\hline & $\begin{array}{c}\text { ヤンク保数 } \\
\mathrm{E}\left(\mathrm{t} / \mathrm{cm}^{2}\right)\end{array}$ & $\begin{array}{c}\text { ポアソン比 } \\
\text { v }\end{array}$ & $\begin{array}{c}\text { 単位体皘重量 } \\
\rho\left(\mathrm{s} / \mathrm{cm}^{3}\right)\end{array}$ & $\begin{array}{c}\text { 世ん断波速度 } \\
\mathrm{Vs}(\mathrm{m} / \mathrm{sec})\end{array}$ \\
\hline \multirow{7}{*}{ 地 } & & GL $0 \sim-58.8 \mathrm{~cm}$ & 0.35 & 0.3 & $1.78 \times 10^{-6}$ & 86.0 \\
\hline & t田 & GL-58.8 - $127.6 \mathrm{~cm}$ & 0.47 & 0.3 & $1.78 \times 10^{-6}$ & 100.0 \\
\hline & & GL-127.6 -177.4cm & 0.59 & 0.3 & $1.78 \times 10^{-6}$ & 112.0 \\
\hline & & GL- $177.4 \sim-250.0 \mathrm{~cm}$ & 0.67 & 0.3 & $1.78 \times 10^{-5}$ & 119.0 \\
\hline & & GL-250.0 - $300.0 \mathrm{~cm}$ & 0.86 & 0.3 & $1.78 \times 10^{-6}$ & 135.0 \\
\hline & 翟 & GL, 0 -600cm & 3.17 & 0.294 & $1.65 \times 10^{-6}$ & 270.0 \\
\hline & & GL-600 -850cm & 5.75 & 0.475 & $1.75 \times 10^{-6}$ & 330.0 \\
\hline
\end{tabular}

\section{2 解析モデルと解析条件}

図 12に解析モデルを示す。この解析モデルは地盤を2 次元FEM解 析モデルをする構造物〜地盤連成系モデルである。解析では GL$8.5 \mathrm{~m}$ の深さ位置に地点によって異なる地霞動を入力するため、地盤 メッシュを入力位置に対応させる必要がある。また、構造物〜地盤 連成系解析モデルは対称であるが入力が一様でないため、対称条件 は適用できず地震応答解析は 2 次元 FEMの全体モデルで行う。解析 条件は次の通りである。

i)構造物模型は曲げせん断型質点系モデル、埋土及び周辺地盤は 2 次 元 FEM解析モデルとした。

ii)深さ方向は観測点が設置されている GL-8.5mで固定境界とし、境 界側面は粘性境界とする。

iii)椿造物模型の諸元を表 1 に地盤物性一覧を表 2 に示す。

iv)減衰定数は材料減衰として構造物模型、地盤に $\mathrm{h}=0.02$ を与え、さ らに地盤には外部減衰として、外部減衰係数 $\beta=11.4 \mathrm{sec}^{-1}$

（T1 =0.11sec で h1 =10.1\%に相当）と仮定した。

\section{3 地震応答解析}

地震応答解析に用いた観測地震波は1985年 8月 12 日福島県沖地震 で図 13に入力波として用いた観測郡録波4X,6Xの加速度応答スペク トルを示す。而記録波の加速度応答スペクトルには顕著な差異は認 められない。ここでは、多入力波の作成方法と多入力波を用いた地 震応答解析法について述べる。

(1)多入力波の作成

解析モデル下部の入力波としての観測記録波は 4X と 6Xの 2 観測 点のみであり、その他の入力波はモデル底面位置での 2 観測波を基

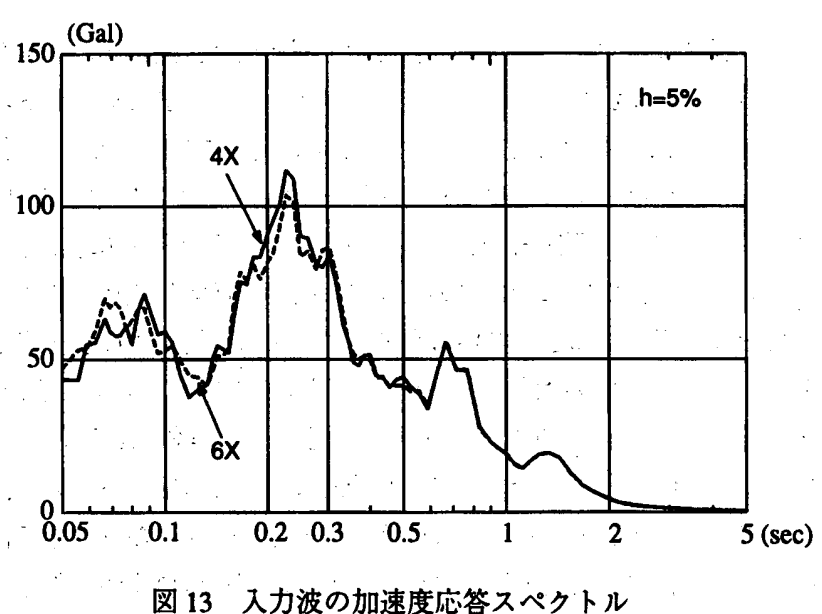

に、振動数毎に位相差を伴う 2 波の合成として解析的に内外㨉して 推定した9)。図 14 に示すように GL-8.5mの $2 つ の$ 観測点を K, J 地 点とする。 $\mathrm{K}, \mathrm{J}$ 地点における観測波のフーリエ変換は任意の円振 動数家成分では次のように表される。

$$
\begin{array}{ll}
A_{k i} \cos \omega_{i} t-B_{k i} \sin \omega_{i} t & (K \text { 地点) } \\
A_{j i} \cos \omega_{i} t-B_{j i} \sin \omega_{j} t & (J \text { 地点) }
\end{array}
$$

\section{ここで次式に示す 2 種類の波(1)，(2)を想定する。}

(1)波 $a_{1 i} \cos \omega_{i} t-b_{1 i} \sin \omega_{i} t=-\sqrt{a_{1 i}{ }^{2}+b_{1 i}{ }^{2}} \sin \left(\omega_{i j} t-\alpha_{1 i}\right)$

(2)波 $a_{2 i} \cos \omega_{i j} t-b_{2 i} \sin \omega_{i} t=-\sqrt{a_{2 i}{ }^{2}+b_{2 i}{ }^{2}} \sin \left(\omega_{i} t-\alpha_{2 i}\right)$

$$
\begin{aligned}
\text { ただし、 } & \\
\tan \alpha_{1 i} & =\frac{a_{1 i}}{b_{1 i}} \\
\tan \alpha_{2 i} & =\frac{a_{2 i}}{b_{2 i}}
\end{aligned}
$$

図 13 に示す加速度応答スペクトルで、4Xと6Xが全く同じであれ ば位相は同位相か逆位相となるが、僅かでも差があれば互いにある 位相差を有する。そこで、(1)波は K, J 地点に同時に入射し、一方 (2)波は K地点において(1)波と同時に入射し、J地点では $\phi_{\mathbf{1}}$ の位相差 を持って入射すると仮定すると次式が得られる。

$$
\frac{a_{1 i}}{b_{1 i}}=\frac{a_{2 i}}{b_{2 i}}
$$

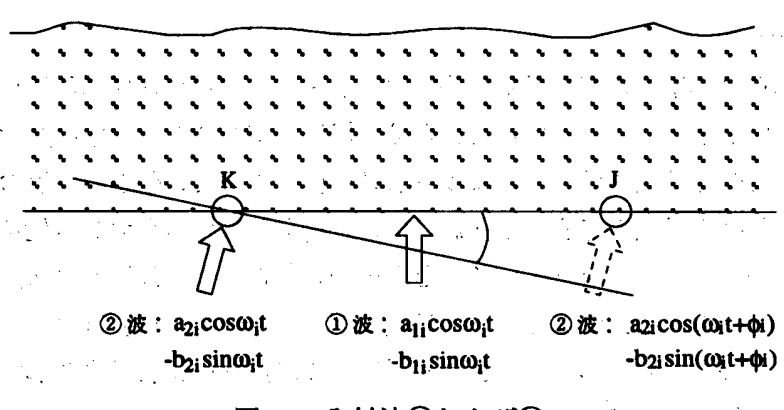

図14.入射波(1)および(2) 
$A_{k i} \cos \omega_{i} t-B_{k i} \sin \omega_{i j} t=a_{1 i} \cos \omega_{i} t-b_{1 i} \sin \omega_{i j} t$ $+a_{2 i} \cos \omega_{i} t-b_{2 i} \sin \omega_{i} t$

$A_{j i} \cos \omega_{i} t-B_{j i} \sin \omega_{i} t=a_{1 i} \cos \omega_{i j} t-b_{1 i} \sin \omega_{j} t$

$$
+a_{2 i} \cos \left(\omega_{i} t+\phi_{i}\right)-b_{2 i} \sin \left(\omega_{i} t+\phi_{i}\right)
$$

ここで既知数 $A_{k i}, B_{k i}, A_{j i}, B_{j i} よ り$ 未知数 $a_{1 i}, a_{2 i}, b_{1 i}, b_{2 i}, \phi_{i}$ を 求めることができる。

したがって K 地点と J 地点の間の $\mathrm{L}$ 地点での $\omega_{i}$ 成分の波形は

$A_{L i} \cos \omega_{i} t-B_{L i} \sin \omega_{i j} t=a_{1 i} \cos \omega_{i} t-b_{1 i} \sin \omega_{i} t$ $+a_{2 i} \cos \left(\omega_{i} t+\phi_{L i}\right)-b_{2 i} \sin \left(\omega_{i} t+\phi_{L i}\right)$

ここで $\phi_{\mathrm{Li}}$ は下図に示すように任意の L 地点と $\mathrm{K}, \mathrm{J}$ 地点の距離よ り得られる。

$$
\phi_{\mathrm{Li}}=\frac{\mathrm{D}_{\mathrm{L}}}{\mathrm{D}} \phi_{\mathrm{i}}
$$

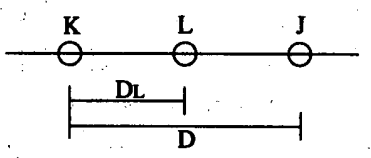

以上のような方法で、図 12 の解析モデル下部の 29 点の入力波を 求めた。入力点の 15 は $4 \mathrm{X} の 、 24$ は $6 \mathrm{X}$ の観測記録と一致している。 (2)多入力地霞応答解析

地霞応答解析はモデル底部での入力地震波が場所によって異なる ため、多入力解析を行なう ${ }^{10)}$ 。以下に解析式を示す。

運動方程式は一般に次式で表される。

$$
\mathbf{M x}+\mathbf{C} \dot{\mathbf{x}}+\mathbf{K x}=\mathbf{P}
$$

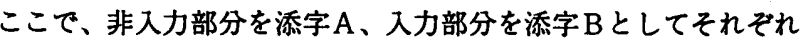
に分解すれば

$\left[\begin{array}{cc}M_{A A} & M_{A B} \\ M_{B A} & M_{B B}\end{array}\right]\left\{\begin{array}{l}\ddot{X}_{A} \\ \tilde{X}_{B}\end{array}\right\}+\left[\begin{array}{ll}C_{A A} & C_{A B} \\ C_{B A} & C_{B B}\end{array}\right]\left\{\begin{array}{l}\dot{X}_{A} \\ \dot{X}_{B}\end{array}\right\}+\left[\begin{array}{ll}K_{A A} & K_{A B} \\ K_{B A} & K_{B B}\end{array}\right]\left\{\begin{array}{l}X_{A} \\ X_{B}\end{array}\right\}=\left\{\begin{array}{l}P_{A} \\ P_{B}\end{array}\right\}$

地震入力の場合には添字 $\mathrm{B}$ 以外の節点 $\left\{\mathrm{X}_{\mathrm{A}}\right\}$ は絶対変位と考える。 いま入力点に強制変位 $\left\{\mathrm{X}_{\mathrm{B}}\right\}$ を与えた時、 $\left[\mathrm{M}_{\mathrm{AB}}\right]=\left[\mathrm{M}_{\mathrm{BA}}\right]=\mathbf{0}$, $\left\{\mathrm{P}_{\mathrm{A}}\right\}=0$ であるから

$$
\begin{array}{r}
{\left[\mathrm{M}_{\mathrm{AA}}\right]\left\{\ddot{\mathrm{X}}_{\mathrm{A}}\right\}+\left[\mathrm{C}_{\mathrm{AA}}\right]\left\{\dot{\mathrm{X}}_{\mathrm{A}}\right\}+\left[\mathrm{K}_{\mathrm{AA}}\right]\left\{\mathrm{X}_{\mathrm{A}}\right\}} \\
=-\left[\mathrm{C}_{\mathrm{AB}}\right]\left\{\dot{\mathrm{X}}_{\mathrm{B}}\right\}-\left[\mathrm{K}_{\mathrm{AB}}\right]\left\{\mathrm{X}_{\mathrm{B}}\right\}
\end{array}
$$

(14)式が求める基本式であるが、ここで絶対変位 $\left\{\mathrm{X}_{\mathrm{A}}\right\}$ を強制変位 $\left\{\mathrm{X}_{\mathrm{B}}\right\}$ と動的変位 $\left\{x_{\mathrm{A}}\right\}$ を用いて次のようにおく。

$$
\left\{\mathrm{X}_{\mathrm{A}}\right\}=\left\{x_{\mathrm{A}}\right\}+\left[\mathrm{D}_{\mathrm{AB}}\right]\left\{\mathrm{X}_{\mathrm{B}}\right\}
$$

ここで、 $\left[\mathrm{D}_{\mathrm{AB}}\right]\left\{\mathrm{X}_{\mathrm{B}}\right\}$ は $\left\{\mathrm{X}_{\mathrm{A}}\right\}$ について静的な鈎合条件を满足するよ うに定める。すなわち

$$
\left[K_{A A}\right]\left(\left[D_{A B}\right]\left\{X_{B}\right\}\right)+\left[K_{A B}\right]\left\{X_{B}\right\}=0
$$

故に、

$$
\left[D_{A B}\right]=-\left[K_{A A}\right]^{-1}\left[K_{A B}\right]
$$

(15)式を微分して
$\left\{\dot{\mathrm{X}}_{\mathrm{A}}\right\}=\left\{\dot{x}_{\mathrm{A}}\right\}+\left[\mathrm{D}_{\mathrm{AB}}\right]\left\{\dot{\mathrm{X}}_{\mathrm{B}}\right\}$

$\left\{\ddot{X}_{A}\right\}=\left\{\ddot{x}_{A}\right\}+\left[D_{A B}\right]\left\{\ddot{x}_{B}\right\}$

(14)式に(15),(18),(19)式を代入して

$\left[\mathrm{M}_{\mathrm{AA}}\right]\left\{\ddot{x}_{\mathrm{A}}\right\}+\left[\mathrm{C}_{\mathrm{AA}}\right]\left\{\dot{x}_{\mathrm{A}}\right\}+\left[\mathrm{K}_{\mathrm{AA}}\right]\left\{x_{\mathrm{A}}\right\}$

$\left.=-\left\{\left[M_{A A}\right]\left(\left[D_{A B}\right]\left\{X_{B}\right\}\right)+\left[C_{A A}\right]\left(D_{A B}\right]\left\{x_{B}\right\}\right)+\left[C_{A B}\right]\left\{x_{B}\right\}\right\}$

よって入力の加速度 $\ddot{\mathrm{X}}_{\mathrm{B}}$ と速度妾 $\mathrm{B}$ が分かれば動的変位・速度・加速 度 $\left\{x_{\mathrm{A}}\right\},\left\{\dot{x}_{\mathrm{A}}\right\},\left\{\ddot{x}_{\mathrm{A}}\right\}$ 少求められ、これを(15),(18),(19)式に代入すれ は絶対変位・速度・加速度 $\left\{\mathrm{X}_{\mathrm{A}}\right\},\left\{\dot{\mathrm{X}}_{\mathrm{A}}\right\},\left\{\ddot{\mathrm{X}}_{\mathrm{A}}\right\}$ 名得られる。

\section{4 解析結果}

解析は入力方法による差の比㜞のため、構造物模型直下の地中観 測点 $(4 \mathrm{X})$ の観測波を 2 次元FEM解析モデルの底面に与える一様入 力と $4 \mathrm{X}$ 及び $6 \mathrm{X}$ の観測記録から得られた多入力の 2 種類を行い、構 造物模型の応答加速度と応答土圧結果を観測記録と比㜞した。解析 結果のうち 2 階床の応答加速度(10X)について観湘記録と比較した。 図 15 に加速度時刻歷波形の比較、図 16 にその加速度応答スペクト ル( $\mathrm{h}=0.05)$ の比較を示した。また、同じ深さの東側と西側の土圧記録 (E1 とW7)の重ね書きを図 17 示した。重ね書きは記録の前半の比較 的振幅の大きい部分と後半の低振動数成分が卓越する部分の 4 秒ず つについて行ない、観測記録、一様入力、多入力の各々の西側側面 の土圧を実線、東側側面の土圧を破線で示している。

\section{5 考察}

解析結果のうち図 $15 に$ 示した構造物模型の 2 階床の加速度時刻歷 波形で比較すると、一様入力、多入力の解析結果の差は振㽞特性を 含めてあまり見られず、两解析結果は観測記録波形とほほ対応して いる。また図 16に示した加速度応答スペクトルで比較しても两解析 結果は観測記録をよく説明している。これは図13に示したように入 力波である $4 \mathrm{X}$ と $6 \mathrm{X}$ の加速度応答スペクトルの差が極めて少ないこ とからも理解できる。しかしながら、図 17に示した相対する側面の 土圧記録の重ね書きで比較すると、一様入力では全て逆位相となっ ているのに対し、多入力では高振動数成分でわずかに逆位相が見ら れるものの低振動数成分では同位相となっていることがわかる。多 入力の結果は観測土圧波形の重ね書きと比較するとよく対応してい るが、一様入力では説明できない。すなわち、土圧記録の位相特性 は地震動の伝播特性を强く反映する。

\section{SV 波の斜め入射による評価}

霞源で生じた地震波は地湸の多くの不連続面で届折、反射を綝り 返し、地表面に達するが、地霞波の伝播速度は地表面に近いほど小 さいため、地表面近くでは地震波はほほ鉛直下方から来ることにな る。遠方地震でも、一般に入射角 $\theta$ が 5゚〜 $10^{\circ}$ と言われており、そ のためP波では上下動が、s波では水平動が卓越する。このため、地 霞応答解析を行なう場合、一般には鉛直下方（入射角 $\theta=0^{\circ}$ ）から 伝わってくるSH波を対象として行なわれる。

上記のような解析は、工学的には妥当であること、、特に構造物の 応答に関してはその挙動をよく説明できることが種々の実証的研究 によって確かめられている。しかしながら、地震時土圧等の実現象 を詳細にみると、地表面近くにおいては、地層構成の不均質性、表 面波等の影響により鉛直下方からのSH波を対象とした解析では表し 

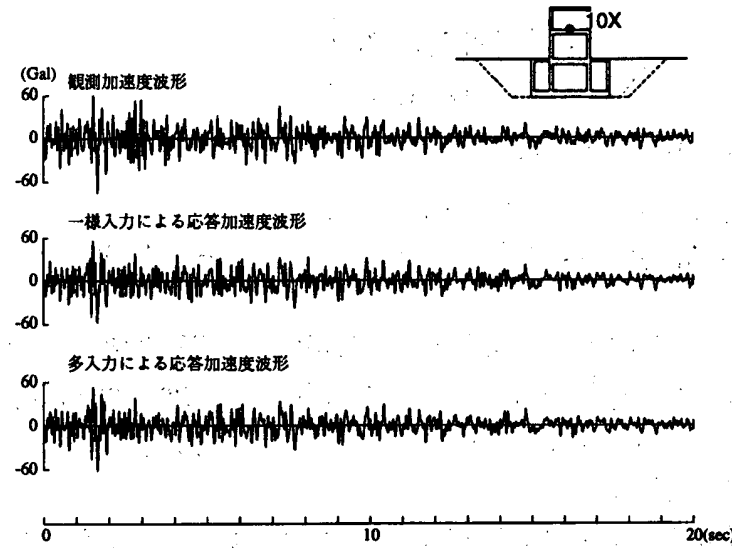

図 15 加速度波形の比較（福島県沖 1985.8.12）

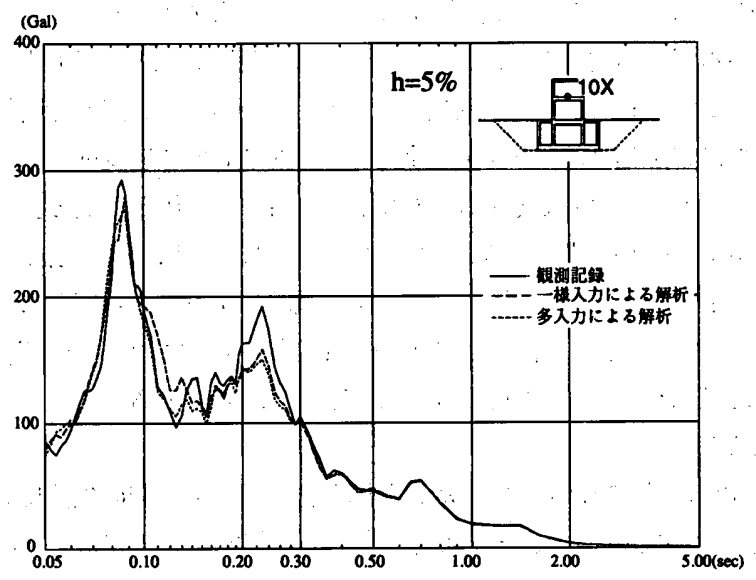

図 16 加速度応答スペクトルの比較（福島県沖 1985.8.12）
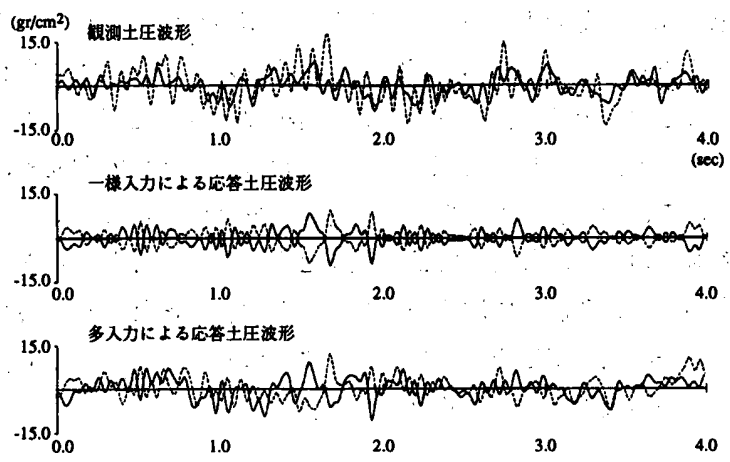

(a) $\mathrm{t}=5 \sim 9$ 秒
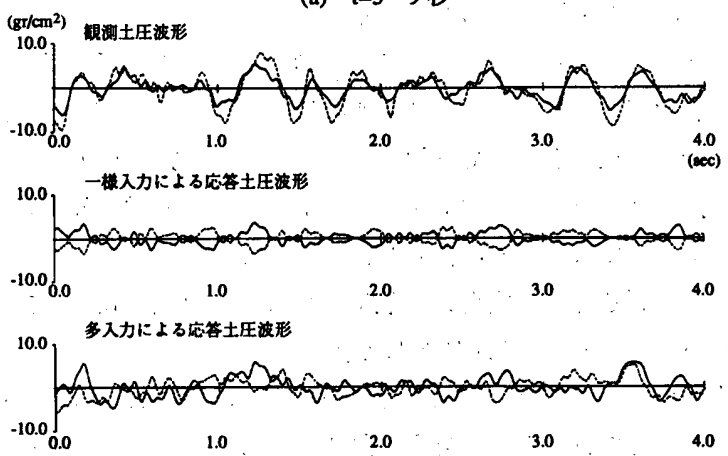

(b) $\mathrm{t}=21 \sim 25$ 秒

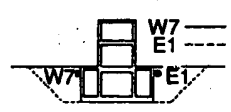

図 17 ，側面土圧の重ね書き・(福島県沖、1985.8.12)
得ない椱雑な挙動を示す。そこで、構造物模型地下部側面の土圧の 位相に着目して、入射角をパラメータとした解析を行なった。

\section{1 解析方法}

、前節では地下部の相対する㑡面の地震時土圧の同位相特性を、解 析モデル底面における入力地震動の振幅、位相の変動を観測記録か ら推定し、多入力解析で説明することができた。しかしながら、こ の解析では 2 所の地震動記録があり、多入力地震動が内外挿可能 であることを前提としている。ここでは土圧の同位相特性をよりー 般性のある解析手法で説明するため、SV波の斜め入射条件を設定し た。なお、地震応答解析における地震波入力は自由地盤の水平動が 地表の観測点 $11 \mathrm{X}$ (GL-0.5m)と一致するようにした。

5.2 解析モデルと解析条件

図18に解析モデルを示す。解析モデルは構造物模型を曲げせん断 型質点系に㯰換し、構造物模型近傍の埋土、周辺地盤の一部を FEM で、支持地盤を一様均質地盤として BEM で評価した 2 次元 FEMBEM のハイブリット：モデルである。解析条件は次の通りである。 i)構造物模型を曲げせん断型質点モデルに置換し、埋土および支持地 盤の一部は図 18 に示す範用を 2 次元 FEM とする。

ii)支持地盤は 2 次元BEMでモデル化し、表層地盤と同じ地盤定数を 有する一様均質地盤に簡略化する。

iii)構造物模型の諸元は前節で用いた表 1 に示す値とする。

iv)埋土と支持地盤の地盤定数は前節で用いた表 2に示す值とするが、

支持地盤はVs=270m/s を有する一様均質地盤とする。

$v$ )減衰定数は材料隇衰として構造物模型、地盤に $\mathrm{h}=0.02$ を与える。 vi)地震応答解析に用いた観測地震波は多入力解析に用いた地震を対

象とする。

\section{3 解析結果}

解析は入射角をパラメータとした周波数応答解析及び地震応答解 析を行なった。解析ケースを図 19に示す。地震応答解析は自由地盤 表層の観測波(11X)をコントロール・ポイントとして入力する。図 20 に入力波となる観測波の加速度応答スペクトルを示す。

(1)周波数応答解析

図 21 図 22 に構造物模型及び埋土表面の自由地表面に対する加 速度の応答倍率を示す。また側面土圧の自由地表面に対する応答倍 率と位相遅れを図 23 に相対する側面について重ね書きして示した。 入射角のパラメータは特徴的な変化が認められる值を選び、加速度 は $\theta=0^{\circ} 、 \theta=-10^{\circ} 、 \theta=-30^{\circ}$ とし、土圧は $\theta=0^{\circ} 、 \theta=-3^{\circ} 、 \theta=-5^{\circ} 、$ $\theta=-10^{\circ} 、 \theta=-15^{\circ} 、 \theta=-30^{\circ}$ とした。

(2)地震応答解析

地震応答解析結果のうち、入射角 $\theta=0^{\circ}$ と $\theta=-10^{\circ}$ を比較して図 24 ～図 25 に構造物模型及び埋土表面の加速度応答スペクトルを示す。 また図 26 に相対する㑡面の土圧(E1 と W7)の重ね曺きを示す。重ね 書きは記録の前半の比較的振幅の大きい部分と後半の低振動数成分 が卓越する部分の 4 秒ずつについて西側側面の土圧を実線、東側側 面の土圧を破線で示している。入射角のパラメータは $\theta=0^{\circ} 、 \theta=$ $-5^{\circ} 、 \theta=-10^{\circ} 、 \theta=-15^{\circ}$ である。

\section{4 考察}

(1)周波数応答解析

構造物の自由地表面に対する応答倍率は入射角が大きくなると若 


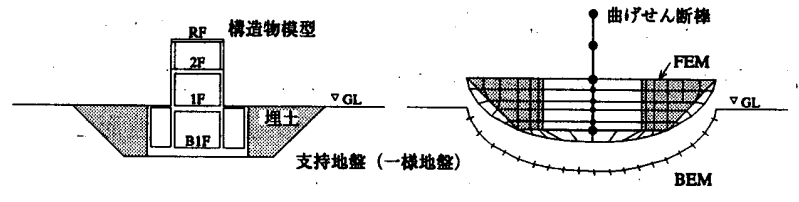

図 18 解析モデル（斜め入射解析）

\begin{tabular}{|c|c|c|}
\hline 解析方法 & 入射角 & 解析策件 \\
\hline \multirow{4}{*}{ 周洨数応答解析 } & $\begin{array}{r}0^{\circ} \\
-3^{\circ}\end{array}$ & 自由地势 \\
\hline & $-5^{\circ}$ & $\vec{x}$ \\
\hline & $-10^{\circ}$ & \\
\hline & $-15^{\circ}$ & ' \\
\hline & $0^{\circ}$ & " \\
\hline \multirow{5}{*}{ 地震店答解析 } & $-3^{\circ}$ & $\hat{\theta}^{\hat{\theta}}$ : 入射角 \\
\hline & $-5^{\circ}$ & \\
\hline & $-10^{\circ}$ & \multirow{3}{*}{ 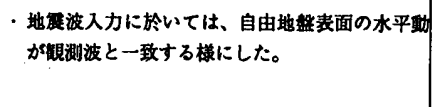 } \\
\hline & $-15^{\circ}$ & \\
\hline & $-30^{\circ}$ & \\
\hline
\end{tabular}

図 19 斜め入射解析 解析ケース一覧

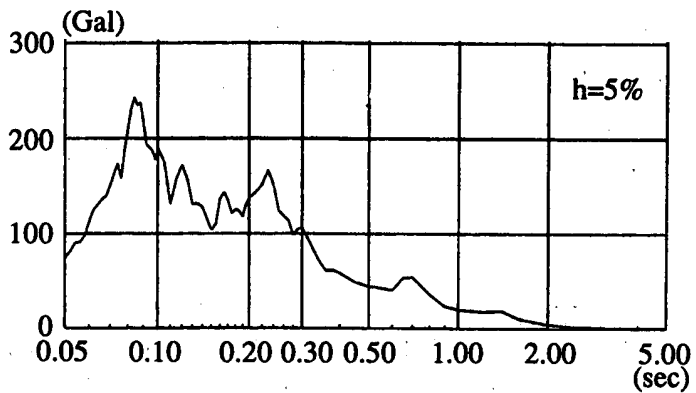

図 20 入力波の加速度応答スペクトル（自由地盤）

干隇少するが、入射角が $\theta=0^{\circ} \sim \theta=-30^{\circ}$ の範囲ではあまり大きく変 化しない。

埋土の応答倍率は振動数が大きくなるに従い大きくなる。また入 射角をもつと構造物模型の前面側 (入射面) の埋土の応答倍率はや や増大、反対側はやや減少する。

側面土圧の応答倍率をみると、入射角が大きい場合高振動数に比 較し低振動数側の増幅が大きい一種のハイカットフィルターの特性 を示し、その傾向は小さい入射角から現れるとともに入射角の増加 に応じて顕著になる。1-次共振振動数近傍においては、構造物模型 の吸振効果により応答土圧値が減少する。位相特性をみると、入射 角 $\theta=0^{\circ}$ の場合、構造物两側の土圧は常に $180^{\circ}$ の位相差をもつのに 対し、入射角をもつ場合、入射角の增加に応じて位相の変化が起こ る。この傾向は低振動数側においてより顕著で、入射角の増加に応

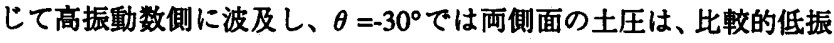
動数部分ではまったく同位相となる。これは入射角が増加するに従 い、角度に応じて地盤自身の圧縮または引張の応力場が卓越し、そ の中に慣性力が小さい構造物があるためと考えられる。

(2)地震応答解析

本解析においては、定性的検討を主眼とし、均質支持地盤の仮定 等の理想化を行なっているため、定量的なシミュレーション解析と いう面では必ずしも妥当な結果が得られているとは言い難いが、観 湘值との比較により以下のことが指摘される。

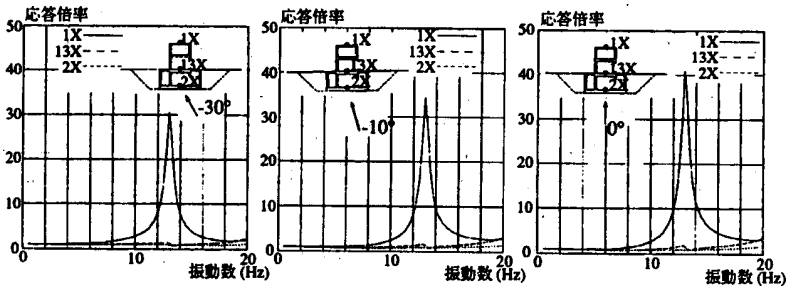

図 21 構造物の自由地表面に対する応答倍率

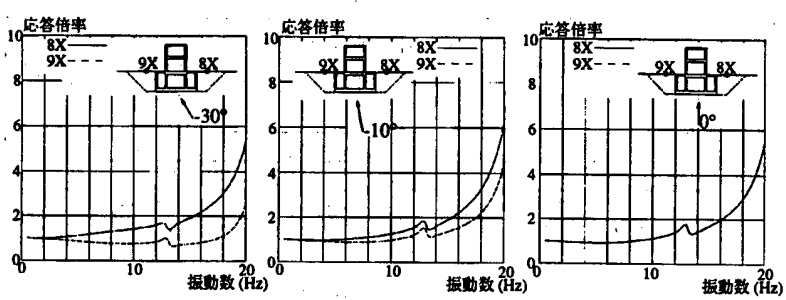

図 22 埋土の自由地表面に対する応答倍率
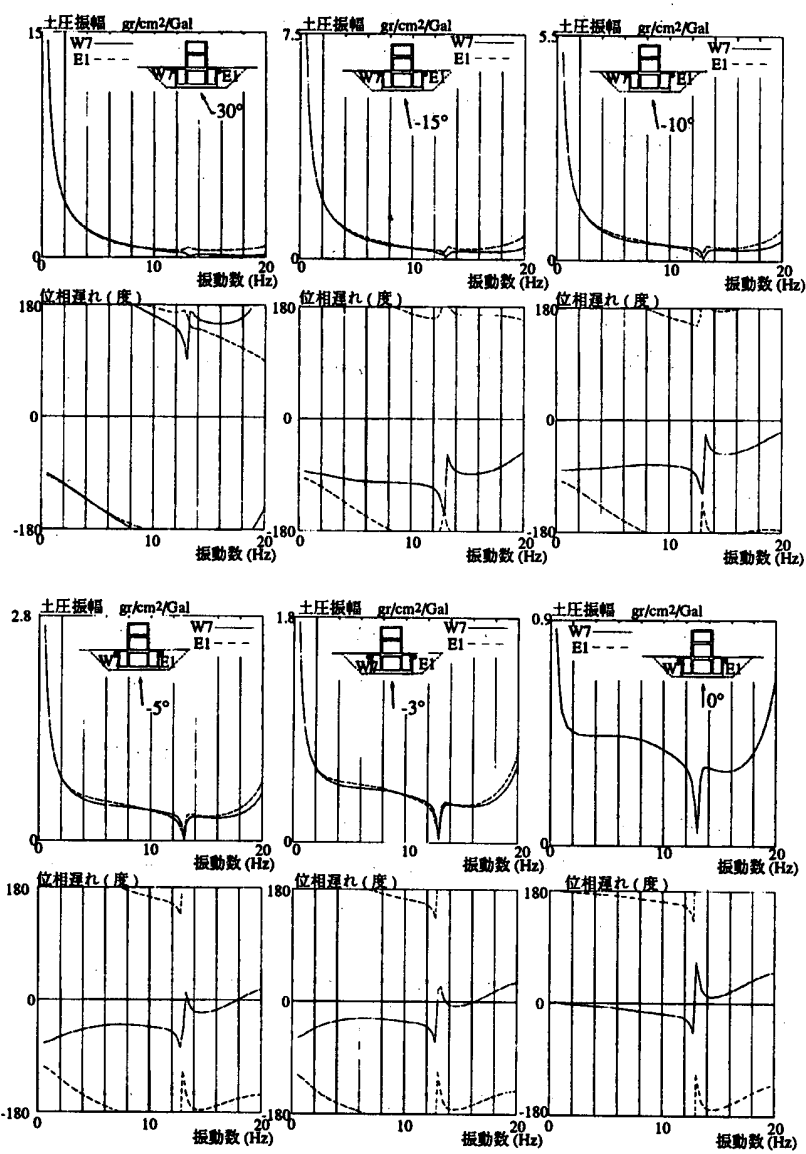

図 23 側面土圧の自由地表面に対する伝達関数

i) 入射角 $\theta=0^{\circ}$ の場合、応答最大土圧值は観測值と比較的よく一致す るが、観測波に見られる比較的低振動数成分及び相対する側面の 同位相土圧については全く表せない。

ii)地震波が入射角をもつ場合、入射角 $\theta$ が $-10^{\circ} \sim-15^{\circ}$ となると相対 する側面の比較的低振動数の同位相土圧についてはその傾向をよ く捉えているが、入射角に比例して土圧値が過大になるとともに 逆位相で現れる高振動数成分については表せない。

iii)入射角 $\theta$ が - 5 $\sim-10^{\circ}$ 程度の場合、土圧波形の時刻歴変化につい 


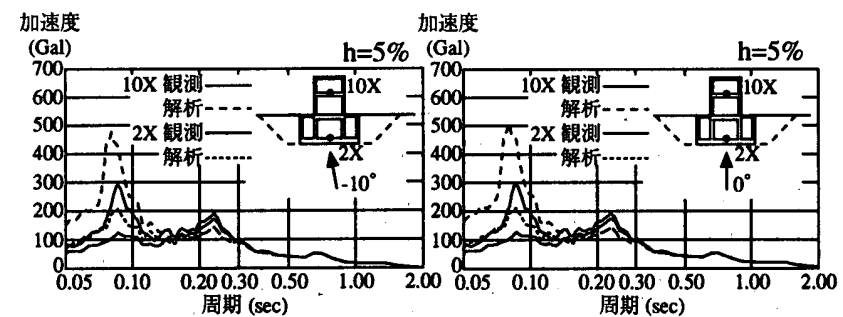

図 24 構造物模型の加速度応答スペクトル

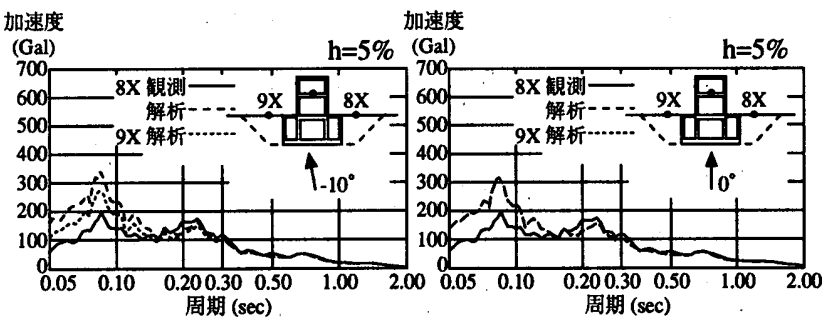

図 25 埋土の加速度応答スペクトル

$$
\begin{array}{r}
(\mathrm{gr} / \mathrm{cm} \\
20 \\
\\
-20 \\
30 \\
\\
-30 \\
30
\end{array}
$$

$\left(\mathrm{gr} / \mathrm{cm}^{2}\right)$

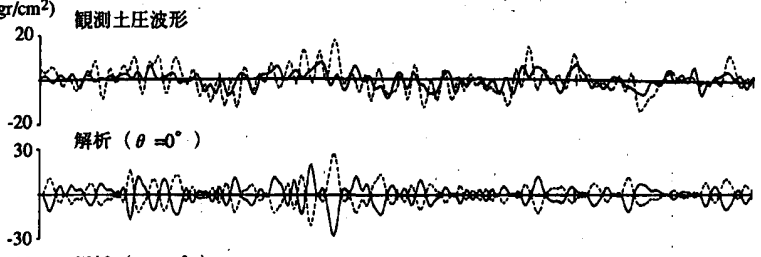

${ }_{-30}^{30}$ 解 $\left(\theta=-^{\circ}\right)$ $-30$

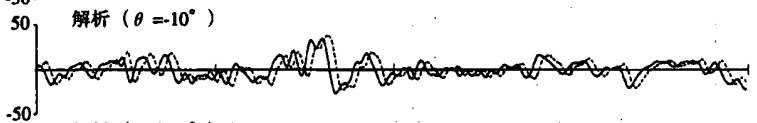

${ }_{50}^{-50}$ 解析 $\left(\theta=-15^{\circ}\right)$

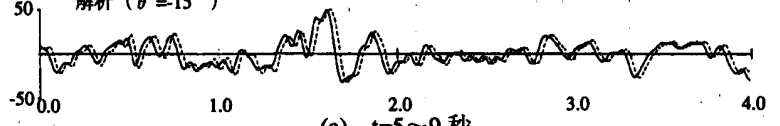

$\left(\mathrm{gr} / \mathrm{cm}^{2}\right)$ 锢测土压波形

(a) $\stackrel{2.0}{\mathrm{t}=5 \sim 9}$ 秒

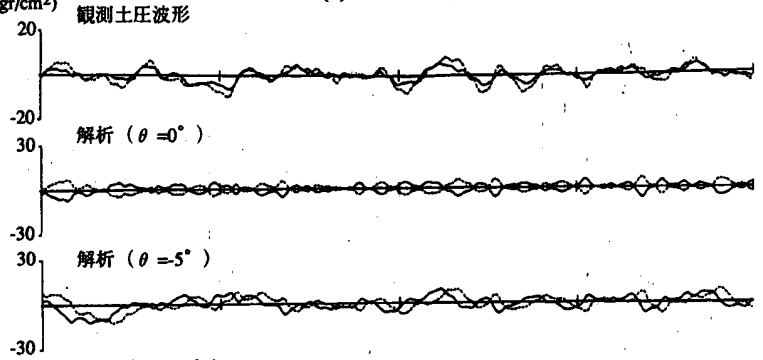

$-30$

50. 解析 $\left(\theta=10^{\circ}\right)$

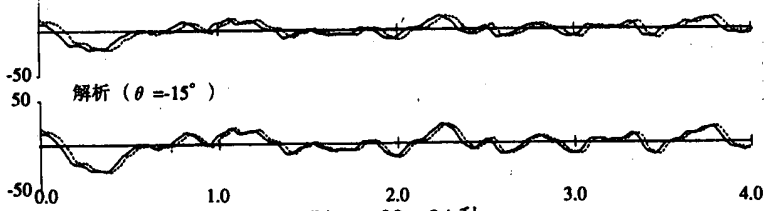

(b) $\mathrm{t}=20 \sim 24$ 秒

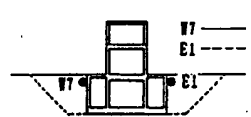

図 26 側面土圧の重ね書き（福島県沖 1985.8.12）

ては、高振動数成分を含む比較的低振動数の土圧、逆位相の高振 動数成分及び土圧の秝対值とも観測值とよい対応を示している。 地下深部の構造を Ichikawa \& Mochizuki のモデル ${ }^{12)}$ を使って入射 角を求めると $-5^{\circ} \sim-10^{\circ}$ に分布しており、本検討と調和している。

\section{6. まとめ}

構造物地下部側面に作用する地震時の土圧は、相対する側面位置 においてかならずしも逆位相ではなく、1次共振振動数よりも低振 動数領域で顕著にみられる同位相土圧と、1 次共振振動数近傍また はそれ以上の振動数領域で発生する逆位相土圧の合成波形となって いることが分かった。これより地震動の構造物への入力がかならず しも SH 波的な伝播ではなく、SH 波や SV 波の斜め入射や入射地震 波が空間的に変動する影響が土圧観測に顕著に現れているものと考 えた。構造物模型と地盤の応答値を時刻歴波形やスペクトルで比較 しても一様入力と多入力の結果に差がほとんど認められなかったが、 相対する側面土圧については一様入力では全ての振動数範囲で逆位 相となっているのに対し、多入力では観測記録と同様に低振動数成 分で同位相となっていることがわかった。

また、SV波斜め入射では入射角 $\theta=0^{\circ}$ の場合、応答最大土圧值は 観測值と比較的よく一致したが、観測波にみられる低振動数成分及 び相対する側面土圧の位相については全く表せない。地震波が入射 角をもつ場合、入射角 $\theta$ が $-10^{\circ} \sim-15^{\circ}$ となると、相対する側面の低 振動数領域の同位相土压についてはその傾向をよく捉えているが、 入射角に比例して土圧値が過大になるとともに、逆位相で表れる高 振動数成分については表せない。入射角 $\theta$ が-5゚〜 -10程度の場合、 土圧波形の時刻歴変化については、低振動数の同位相土圧、高振動 数領域の逆位相の傾向とよく対応する。またこの程度の入射角は、 地震波の入射角として一般的と考えられる值とも对応している。

\section{参考文献}

1)政尾 亨, 河田額治, 清水信行, 平沢光春, 桑折能彦, 高崎芳夫, 落合 茂 :深い基礎の振動特性の実験的研究 (その 1 実験の意義とその計面)，(そ の 2 振動実験結果), 日本建築学会大会学術講演梗概集, pp.551-554, 昭和 51 年 10 月

2)藤森健史，和泉正哲，角田智彦，秋野金次：大型模型試験体強制振動試験に おける周辺地盤波動伝播特性と逸散減衰特性評価, 第 8 回日本地震工学シン ポジウム, pp.1011-1016, 1990

3)福岡篤信, 和泉正哲, 宮本裕司, 大塚康弘：埋込み構造物と地盤の動的相互 作用試験, 第 8 回日本地震工学シンポジウム, pp.1029-1034, 1990

4)Kaizu N., Sugi T., Kuwahara H., Suzuki H.:Obseravation and Numerical Analyses of Dynamic Earth-Pressure of In-Ground LNG Tanks,Proceedings of 9th WCEE, Vol.VI, pp.685-690, 1988

5)国吉秀城，深掘康夫，色摩康弘，千葉 脩，渡壁守正; 保井美敏：深い根入 れを有する建築物の地震観測（その 8 最大地震時変動側圧の検討）, 日本 建築学会大会学術講演梗概集, pp.565-566, 1992年 8 月

6)H.Tanaka, T.Ohta, S.Uchiyama : Experimental and Analytical Studies of a Deeply Embedded Reactor Building Model Considering Soil-Building Interaction (Part-I). Transactions of the 5th SMiRT, Vol.K(a), K7/8, Aug. 1979, (Part-II).6th SMiRT, Vol.K(a), K4/10, Aug. 1981,(Part-III).7th SMiRT, Vol.K(b), K9/9, Aug. 1983

7)M.Narikawa, Y.Inagaki, S.Uchiyama,M.Kanechika. : Experimental and Analytical Study on Earth Pressure of a Embedded Building Model During Earthquake. Transactions of the 10th SMiRT, Vol.K1, pp.235-240, Aug. 1989

8)太田外気晴, 足立憲彦, 越田 洋, 稗戋成人:岩盤アレー観測記録の解析 (そ の3 館山小アレー観測別録の解析), 日本建築学会大会学術講演梗概集, pp.543-544, 昭和 56 年 9 月

9)田中宏志, 吉田一, 成川匡文, 太田外気晴, 内山正次, 稗戋成人: 地震動 の有効入力評価の一手法(その 1 有効入力波の推定)，(その2 統計的処 理による有効入力波の評価)，日本建築学会学術講演梗概集, pp.829-832, 昭 和 58 年

10)桜井彰雄, 高橋 忠, 條原千鶴子, 矢島 浩: 長大構造物の地震応答解析 についての一考察, 第 3 回日本地震工学シンポジム, pp.429-436, 1970

11)稲垣善信, 内山正次：地震時側面土圧の位相特性について（その 1 地震 観測結果), (その 2 解析的検討), 日本建筑学会学術講演梗概集 B,pp.813816, 昭和 63 年

12)Ichikawa \& Mochizuki : Travel Time Tables for Local Earthquakes in and near Japan, Papers in Meteor. Geophys. 22, 1971 